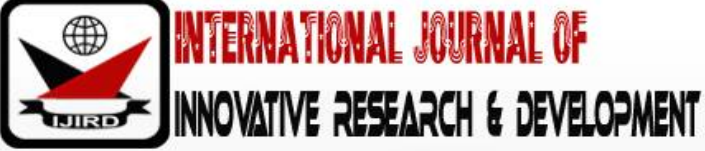

ISSN 2278 - 0211 (Online)

\section{The Role of Strategic Sourcing and Supply Chain Agility on Firm Performance: Case Study of SMEs in Traditional Market}

\section{Ikhwansyah Syakur Ma'mun}

Student, Department of Economics, Islamic University of Indonesia, Yogyakarta, Indonesia

\begin{abstract}
:
Cooperatives, Small and Medium Enterprises, and Micro, Small and Medium Enterprises (MSMEs) have an important and strategic role in national economic development. In addition to helping in economic growth and development of labor, MSMEs also support the development of development outcomes. MSMEs are now circulating in the market especially traditional markets. Traditional markets are beginning to decline with the demand for supermarkets and other retail businesses. Especially now that the online age, management of MSMEs and SMEs must be able to compete with online shops as well. The main challenge for management in promoting innovation and how it is applied to new innovations is the number of binding things such as regulation and wisdom. This study aims to analyze the strategies for developing traditional market performance in this disruptive and dynamic era by increasing strategic sourcing and strategic agility. In addition, this study also aims to supply chain agility in traditional markets as a moderation of the relationship between strategic sourcing towards the performance of traditional markets. Empirical results are obtained through the distribution of questionnaires to 200 traditional market managers in Sleman, Yogyakarta. The study conducted structural equation modeling to test the proposed relationships. The result show that supply chain agility has a significant influence on firm performance but strategic sourcing does not have a significant effect on firm performance, while strategic sourcing has a significant effect on supply chain agility. The study results may help managers of traditional market to implement strategic sourcing and supply chain agility to develop traditional market's performance.
\end{abstract}

Keywords: Traditional market, MSME's, strategic sourcing, supply chain agility, and firm performance

\section{Introduction}

Micro, Small and Medium Enterprises or abbreviated as MSMEs have an important and strategic role in national economic development. In 2018 the number of MSME players in Indonesia is predicted to reach 58.97 million by Data from the National Development Planning Agency, the Central Statistics Agency, and the United Nation Population Fund (Smartlegal.id, 2019).

The contribution of the micro, small and medium enterprises (MSMEs) sector to the national gross domestic product is projected to grow 5\% throughout 2019. According to Chairman of the Association of Indonesian Micro, Small and Medium Enterprises (Akumindo) Ikhsan Ingratubun, with the estimated growth, he believes the total contribution of MSMEs National gross domestic product (GDP) this year can reach 65\% or around Rp2,394.5 trillion. Meanwhile, the realization of the contribution of MSMEs to national GDP last year reached around 60.34\%. Meanwhile, according to economist at the Institute for Development of Economics and Finance (Indef) Bhima Yudhistira assessed, the projected growth of MSME contribution to GDP by 5\% in 2019 is quite realistic, because it is in line with the estimated economic growth ranging from 5\% -5.2\%. (Ekonomi.bisnis.com, 2019).

There are many MSMEs on the market, including traditional markets. With the advancement of the era as now MSMEs must compete with many new competitors. Therefore, managers must be agile and able to see an opportunity to create a new strategy, and move the organization in a new direction, namely they need to balance regulatory changes (rulechanging) and applicable regulations (rulefollowing) (Schermerhorn, 2010).

MSMEs in order to compete with new competitors, several studies offer solutions to improve MSME performance, one of them is strategic sourcing. Strategic sourcing is the process of planning, implementing, monitoring and evaluating important decisions to achieve the company's long-term goals and plans (Carr, 2002). The main objective of Strategic sourcing is to reduce uncertainty and increase flexibility for better handling of uncertainties in supply, demand and competitiveness (Sinha, 2011).

Strategic sourcing can't be separated from the supply chain agility, so that MSMEs can develop rapidly must adapt to a changing environment by acting agile (Nagel, 1991). The level of supply chain agility of a company is the ability to adapt the relationship between the company and its market (Murthy, 2008). Supply chain agility in terms of responsiveness, 
changes as opportunities, flexibility, customization, mobilization of core competencies, integration, structure and organizational speed (Holcomb, 2012a).

Strategic sourcing and supply chain agility is one solution for managers to improve company performance. In measuring company performance using Entrepreneurial performance, Business performance and Strategic goals (Tomljenović and Stilin, 2010). Performance is a term in general that is used for part or all of the actions or activities of an organization in a period with reference to the number of standards such as past or projected costs, with the basis of efficiency, accountability or management accountability and the like (Srimindarti, 2004).

Many strategic sourcing and supply chain agility studies support to improve company performance, including MSMEs. Like previous studies conducted (Rajesh K. Pillania, 2008), which shows a significant influence between sources strategies and their dimensions of supply chain agility and company performance.

Research conducted by (Chai, 2017) that supplier activity positively influences information exchange and supply chain agility but does not have a significant relationship with the source's strategy. Both information sharing and strategic sourcing play a positive role in improving Supply Chain Agility. This study also offers empirical evidence that the impact of supplier innovation, Information Sharing and Strategic Sourcing in domestic supply chain agility is stronger than global sources.

Research conducted by (DeGroote, 2013), shows that IT increases supply chain agility to sense changing markets by increasing the adequacy, accuracy, accessibility, and timeliness of information flow in the supply chain. IT also enhances supply chain capabilities to respond to market changes by reducing costs, improving quality, developing and implementing plans to respond to market changes in the supply chain. The results showed that increased supply chain agility had a positive impact on company sales, market share, profitability, market speed, and customer satisfaction.

In the performance of MSMEs, managers must have a strategy to bring their companies to compete with other competitors. As technology advances are increasingly rapid, managers must start making long-term strategies. Management must also be able to be nimble and dynamic in the face of changing markets. With MSMEs and those spread in traditional markets, and registered with the Department of Industry and Trade, MSME managers must collaborate with the market and service agencies. Based on the above problems and previous research, this study examines more deeply the relationship between Strategic Sourcing and Supply Chain Agility in the performance ofMSMEs in the Traditional Market of Sleman Regency.

\section{Literature Review}

\subsection{Strategic Sourcing and Supply Chain Agility}

Strategic Sourcing is the process of planning, implementing, monitoring and evaluating carried out by companies in choosing decisions that are very important to achieve the company's long-term goals and plans (Carr, 2002). Strategic Sourcing is the process of designing and managing a supply network in accordance with the operational and organizational performance objectives (Narasimhan and Das, 1999a, b). The Strategic Sourcing concept has evolved over the past two decades and is measured by four sub-construction Strategic Purchases, Internal Integration, Information Sharing, and Supplier Development (Suresh, 2006).

Supply chain agility is the ability of an organization's internal supply chain function to provide strategic benefits by responding to market uncertainty. Just as companies achieve competitive advantage using different strategies, supply chain agility can be achieved in various ways. Agility is related to agility, speed, and agility; while flexibility is related to adaptability and flexibility (Kidd, 2000).

Supply Chain Agility can be achieved by developing and acquiring systematically the ability that can make the supply chain act fast and various environmental and competitive changes (Khan, 2006). Agile supply chains are capable of rapid adaptation in response to unexpected things, changes and events, market opportunities, and customers (Goldman, 1994).

The relationship between strategic sourcing and supply chain agility is supported by other studies conducted by (Chiang, 2011), (Chai, 2017) as well as research conducted by (Pauline Jeruto Keitany, 2017) in that the study has a significant positive effect. The research uses one dimension of purchasing strategy, internal integration, information sharing, and supplier development. This dimension supports research to measure the influence of strategic sourcing.

\subsection{Supply Chain Agility and Firm Performance}

Supply chain agility can be established in business processes and structures that facilitate the speed of adaptation and robustness, and that are able to achieve competitive performance dynamically and high business environments that cannot be predicted (Kidd, 2000). Expanding this definition by discussing agility in terms of relationships between suppliers, customers and producers. (Braunscheidel, 2009). There are five dimensions, among others - flexibility, effectiveness, speed, reliability, and visibility - which are used to measure supply chain agility (Charles, 2010).

Performance is a description of the level of achievement of the task in an organization, in an effort to realize the goals, objectives, mission, and vision of the organization (Bastian, 2001). Company performance can be measured by several different dimensions. (Tomljenović \& Stilin, 2010) conducted research related to company performance using Entrepreneurial performance, Business performance and Strategic goals to measure company performance. Company performance can be seen from the speed of work processes, reliable quality and good service. According to Mashun(2006), the performance of the company is a process of determining the ability of work to the goals and objectives that have been determined in producing quality goods or services.

Many studies that show a significant positive influence between supply chain agility towards firm performance include, (DeGroote, 2013, (Kim, 2012), (Barua, 2013), and (Sabegh, 2018). The first four steps capture how effectively the 
value chain provides products to meet customer demand and the rest reflect the ability to respond to markets in a timely manner. The overall delivery time for existing products is influenced by the manufacturing cycle time and delivery time, while the delivery time for new products is also a function of the time needed to develop products from initial concepts to fruition (Rajesh K. Pillania, 2008) so that according to the study they use several dimensions, namely:

- Management and distribution demand

- Manufacturing and customization

\subsection{Strategic Sourcing and Firm Performance}

Performance and Strategy are ways to ensure sustainable competitive advantage by investing the resources needed to develop profitable storage capabilities, performance will excel superior performance (Li, 2014). Organizations use strategies against environmental changes because they have the ability to hide situations within the organization. The basis of this strategy involves decision making, the content of the strategy, and the process by which actions are decided and implemented (Anwar, 2017).

Performance management must relate to strategic planning and organizational direction, budget processes, employee development plans and improvement programs such as wages or wage rates, rewards and promotions (Sarrico, 2012). To measure organizational performance, it can be through a subjective approach to management capability because management capabilities are better able to reflect in terms of strategies, abilities, and appropriate performance in making strategic decisions in the organization subjectively.

The influence of strategic sourcing on firm performance in many studies has a significant positive effect, among others: (Rajesh K. Pillania, 2008), (Smeltzer, 1999), and (Injazz J. Chena, 2004). In this study to measure company performance using dimensions: Entrepreneurial performance, Business performance and Strategic goals (Tomljenović \& Stilin, 2010).

\section{Research Methods}

The population used in this study is MSMEs in traditional markets managed by the Office of Industry and Trade of Sleman Regency. The samples used in this study were 200 SMEs in the traditional market in Sleman Regency.

The data to be used in this study was obtained through the distribution of questionnaires to 200 MSMEs in traditional markets. Then the data were analyzed using the Structural Equation Model (SEM) method using AMOS software.

The variables analyzed in this study are strategic sourcing, supply chain agility and firm performance with the following definitions and indicators:

\subsection{Strategic Sourcing}

Strategic sourcing aims to identify and select suppliers for the long term, as well as engage in initial supplier activities and supplier development by maximizing resources effectively to improve supplier performance and be measured by four sub-construction Strategic Purchases, internal integration, information sharing, and supplier development (Suresh, 2006). The indicators of strategic sourcing are as follows (Chiang, 2011):

\subsubsection{Purchasing Strategies}

- Top management emphasizes the strategic role of the purchasing function

- Purchases are seen as the same as other functions by the CEO

- Purchases involved in company-level strategic planning

\subsubsection{Internal Integration}

- There is often communication between purchases and other departments in our company

- Purchasing personnel included in the engineering team together

- Purchasing executives receive cross-functional training

\subsubsection{Information Sharing}

- Distribution of information on production schedules with suppliers

- Production scheduling synchronized with suppliers

- Share information on costs with suppliers

\subsubsection{Supplier Development}

- Financial assistance to suppliers

- Technology assistance for suppliers

- Training on quality issues to supplier personnel

\subsubsection{Supply Chain Agility}

The literature review of supply chain performance metrics provides a measure of performance, namely the delivery of timely customer orders, reorder rates, depleted inventory percentage, delivery time after receiving customer orders, manufacturing cycle times, supply chain cycle times, capacity utilization, time to market (Van Hoek, 1998). So according to this study using several dimensions, namely (Rajesh K. Pillania, 2008): 


\subsubsection{Demand Management and Distribution Indicator}

- Supply chain capability to exchange information quickly;

- The ability of the supply chain to predict changes quickly;

- Supply chain capabilities adjusted to supplier delivery schedules;

- The ability of the supply chain to rapidly reduce inventory; and

- The ability to quickly reduce order cycle times to delivery.

\subsubsection{Manufacturing and Customization Indicator}

- Supply chain capabilities to rapidly reduce installation costs;

- Supply chain capability to quickly reduce installation time;

- The ability to quickly reduce product development cycle times;

- the ability to quickly reduce manufacturing time;

- The ability to quickly improve the capabilities of manufacturing processes; and

- The ability to adjust quickly with customization.

\subsection{Company Performance}

Company performance can be described in various aspects, both from the financial aspect, company productivity, to employee performance. However, in this study company performance is measured by entrepreneurial performance, business performance and the company's strategic objectives. The measurements are as follows (Beheshti, Mostaghel and Hultman, 2014):

- $\quad$ MSMEs are able to make cost reduction efforts

- High return on capital

- Sales increase

- Assets have a good rate of return (Comparison income and assets continue to increase)

- MSMEs have good liquidity (cash)

- Net profits continue to increase

\section{Result}

\subsection{Confirmatory Analysis}

Confirmation analysis is used to test concepts that are built using several measurable indicators. The conformity model conformity test was tested using the Goodness of Fit Index which included Chi-Square, probability, RMSEA, GFI, CFI, TLI and CMIN / DF. This study uses 7 variables which include strategic purchasing with 4 indicators, internal integration with 4 indicators, information sharing with 4 indicators, supplier development with 4 indicators, management and distribution standards with 4 indicators, Manufacturing and customization with 4 indicators and company performance with 6 indicators and total indicators are 30 which can be seen from AMOS 24 analysis.

According to Hair et al. $(2010,777)$ the minimum number of factor loading is $\geq 0.5$ or ideally $\geq 0.7$. So that it can be concluded that all the questions used to measure the variables in this study are declared valid. From these results it is known that there are indicators that are still below 0.5, namely the SS3 indicator, so it must be removed from the research model.

From the results of the goodness of fit test, it was found that only one criterion was fulfilled, namely RMSEA, while the other criteria were not fit, so modification of the model with reference to modification indices that required eliminating some indicators was obtained so that new criteria were met as all where table the results of the goodness of fit test are as follows (Table 1):

\begin{tabular}{|c|c|c|c|}
\hline Goodness of Fit & Criteria & Cut-off Value & Information \\
\hline Chi-Square (X2) & Expected to be small & 273.787 & Fit \\
\hline Significance Probability & & & \\
\hline RMSEA & $\geq 0,05$ & 0.239 & Fit \\
\hline GFI & $\leq 0,08$ & 0.018 & Fit \\
\hline AGFI & $\geq 0.90$ & 0.913 & Fit \\
\hline CMN/ DF & $\geq 0.90$ & 0.864 & Marginal Fit \\
\hline TLI & $\leq 2,00$ & 1.061 & Fit \\
\hline CFI & $\geq 0,90$ & 0.988 & Fit \\
\hline & $\geq 0.90$ & 0.992 & \\
\hline
\end{tabular}

Table 1: Goodness of Fit

\subsection{Reliability Test}

The reliability coefficient ranges from $0-1$ so that the higher the coefficient (close to number 1 ), the more reliable the measuring instrument. Good construct reliability if the construct reliability value is $>0.7$ and the variance extracted value is $>0.5$ (Yamin \& Kurniawan, 2009). 


\begin{tabular}{|c|c|c|c|}
\hline Variable & Indicator & $\mathbf{C R}$ & $\mathbf{V E}$ \\
\hline Strategic Purchasing & $\begin{array}{l}\text { SS1, SS2, } \\
\text { SS4 }\end{array}$ & 0.6 & 0.5 \\
\hline Internal Integration & $\begin{array}{l}\text { SS5, SS6, } \\
\text { SS7, SS8 }\end{array}$ & 0.6 & 0.6 \\
\hline Information Sharing & $\begin{array}{c}\text { SS9, } \\
\text { SS10, } \\
\text { SS12 }\end{array}$ & 0.6 & 0.5 \\
\hline Supplier Development & $\begin{array}{l}\text { SS13, } \\
\text { SS14, } \\
\text { SS15, } \\
\text { SS16 }\end{array}$ & 0.6 & 0.4 \\
\hline $\begin{array}{c}\text { Costumer } \\
\text { Responsiveness }\end{array}$ & $\begin{array}{l}\text { SC1, SC2, } \\
\text { SC3, SC4 }\end{array}$ & 0.7 & 0.5 \\
\hline Demand Response & $\begin{array}{l}\text { SC5, SC6, } \\
\text { SC7, SC8 }\end{array}$ & 0.7 & 0.5 \\
\hline Firm Performance & $\begin{array}{l}\mathrm{K} 1, \mathrm{~K} 2, \\
\mathrm{~K} 3, \mathrm{~K} 4 \\
\mathrm{~K} 5, \mathrm{~K} 6\end{array}$ & 0.7 & 0.5 \\
\hline
\end{tabular}

Table 2: Reliabilities Test

From table 2, it can be recognized that construct reliability 3 variables have shown 70.7 but there are also 4 other variables which only have values CR 0.6, but Ferdinan (2002) states that CR can still be accepted with a value above 0.5. As for the variance extracted in the Supplier Development variable, it is still less than 0.50, but according to Hatcher in Longino (2007) states that variance extracted testing is conservative, reliability can be accepted even if the extracted variance is less than 0.50 . So, it can be concluded that the questionnaire used for this study was declared reliable.

\subsection{SEM Analysis}

Model development in this study is based on the concept of data analysis described in chapter II. In general, the model consists of exogenous variables, namely Strategic purchasing, internal integration, information sharing, supplier development, customer support, demand response. While the endogenous variables in this study are firm performance.

The next step is to develop quality relationships with path diagrams and construct structural equations. There are 2 things that need to be done, namely structuring a model that is by connecting between latent constructs both endogenous and exogenous to compile and determine the model that is connecting endogenous or exogenous land constructs with an indicator variable or manifest. Structural equations and measurement models that have been adjusted to the results of confirmatory analysis are as follows:

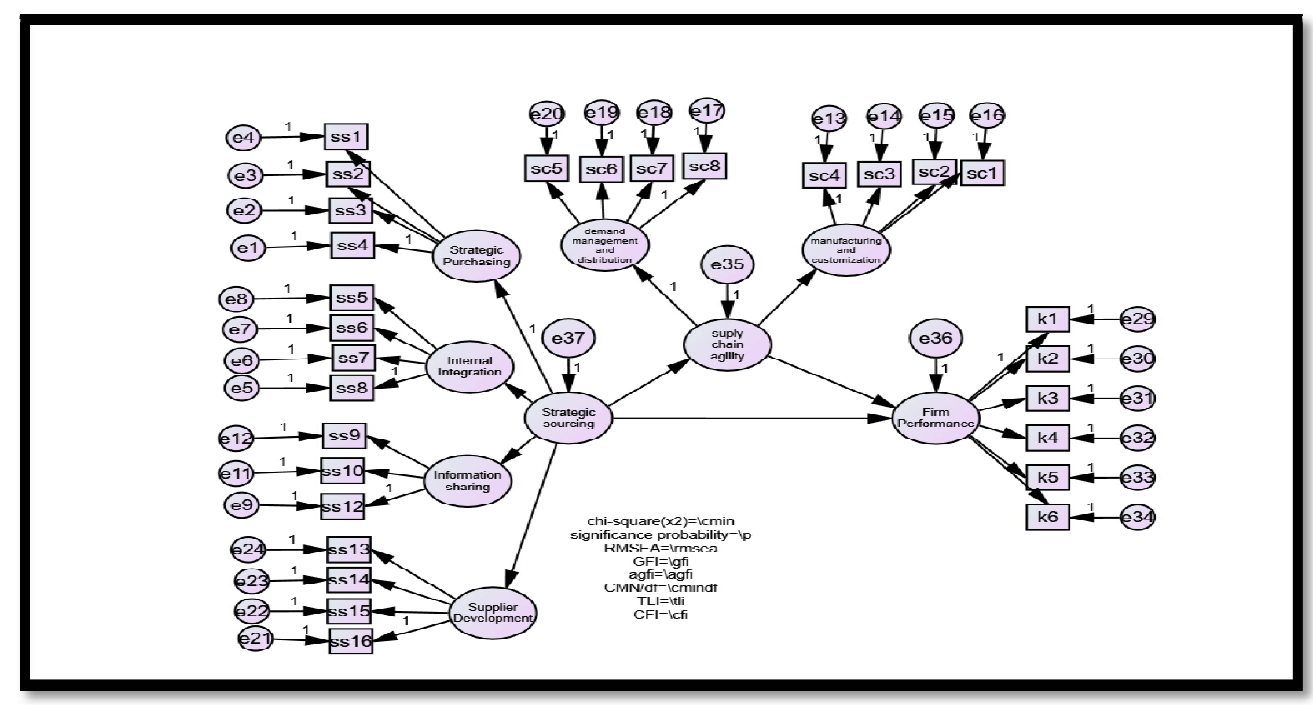

Figure1

Structural equation models differ from other multivariate analysis techniques. SEM only uses input data in the form of a variance matrix or covariance or correlation metric. The estimated model used is estimation maximum likelihood (ML) which has been fulfilled with the following assumptions:

\subsubsection{Sample Size}

Sample size refers to the number of data samples that must be fulfilled, namely as many as 100-200 samples. In this study it has been fulfilled with a sample of 200 . 


\subsubsection{Data Normality}

The normality data assumption must be fulfilled so that data can be processed further for SEM modeling. Univariate normality testing is to observe the value of skewness and kurtosis data used, if the CR value of skewness and CR in kurtosis data is between \pm 2.58 , then the research data can be said to be normal.

Based on the normality test obtained there are several values of $\mathrm{cr}$ that are outside between \pm 2.58 . Cr values that are outside the range are smaller than those that meet the criteria. Because it can be explained that normal distribution. So, it can be concluded that univariate is normally distributed. While the multivariate test gives a value of cr 4.36 , where the value is still below 10,000. according to Ghozali (2006) data below 10,000 can be concluded that the data generated is not normally distributed multivariate.

\subsubsection{Outliers}

Outliers are observations or data that have unique characteristics that look different from other observations and appear in the form of extreme values, both for a combination variable and variable. The outliers can be evaluated using an analysis of multivariate outliers seen from the value of the Mahalanobis Distance.

The Mahalanobis Distance test is calculated using the chi-square value of the degree of freedom of 28 indicators at the level of $p<0.001$ using the formula X2 $(28 ; 0.001)=56.89$. The outlier test did not find a value of more than 56.89 so it can be concluded that the data is not outliers. Furthermore, SEM requires the research model to meet the criteria of goodness of fit. However, the previous results give results that do not meet the criteria of goodness of fit, therefore action must be taken renewal or improvement. The corrective actions taken in this analysis are with issuing observations containing outliers and modifying models through modification indices and removing variables containing outliers.

After reforming and updating by removing the value of observations containing outliers and modifying the model, the results of the goodness of fit test are obtained as table 3.

\begin{tabular}{|c|c|c|c|}
\hline Goodness Of Fit & Criteria & Cut-Off Value & Information \\
\hline Chi-Square (X2) & small & 232.924 & Fit \\
\hline Significance Probability & $\geq 0,05$ & 0.191 & Fit \\
\hline RMSEA & $\leq 0,08$ & 0.02 & Fit \\
\hline GFI & $\geq 0.90$ & 0.92 & Fit \\
\hline AGFI & $\geq 0.90$ & 0.869 & Marginal Fit \\
\hline CMN/ DF & $\leq 2,00$ & 1.083 & Fit \\
\hline TLI & $\geq 0,90$ & 0.982 & Fit \\
\hline CFI & $\geq 0.90$ & 0.988 & Fit \\
\hline
\end{tabular}

Table 3: Goodness of Fit

Based on table 3, it is known from all existing goodness of fit criteria, all criteria have been fulfilled by this research model. All criteria are good or fit except AGFI values that are still marginally fit but can be tolerated and this research model can be said to be good or meet the criteria of goodness of fit.

The next analysis is the analysis of the Structural Equation Model (SEM) in full model to test the hypotheses developed in this study. The regression weight test results in this study are as follows (Table 4):

\begin{tabular}{|l|c|c|c|c|c|c|}
\hline & & & Estimate & S.E. & C.R. & P \\
\hline Suply_chain_agility & $<---$ & Strategic_sourcing & 1.451 & 0.289 & 5.014 & 0 \\
\hline Firm_Performance & $<---$ & Suply_chain_agility & 0.61 & 0.24 & 2.544 & 0.011 \\
\hline Firm_Performance & $<---$ & Strategic_sourcing & 0.147 & 0.376 & 0.39 & 0.696 \\
\hline
\end{tabular}

Table 4: Uji Hipotesis

To see the hypothesis accepted or rejected, by looking at the value of Critical Ratio (CR) and probability value (P) from the results of data processing. If the test results show a CR value above 1.96 and the probability value (P) is below $0.05 / 5 \%$, the proposed hypothesis is declared acceptable. In detail the research hypothesis testing will be discussed in stages according to the hypothesis that has been proposed.

In this study 3 hypotheses were proposed, the discussion of which will be further described as follows:

- H1: Strategic Sourcing has a significant effect on Supply Chain Agility

- H2: Supply Chain Agility has a significant effect on Firm Performance

- H3: Sourcing strategies have a significant effect on Firm Performance

\section{Discussion}

\subsection{Relationship of Variable Strategic Sourcing to Supply Chain Agility}

Based on the results of the analysis prove that strategic sourcing has a significant positive effect on the performance of MSME firms in sleman traditional markets, based on data processing (Table 4) it is known that the value of CR 5.014 and $P$ value is 0.000 . These results indicate that the CR value is still below 1.96 and the $P$ value is below 0.05 . The estimated value in relation to these two variables is 1,451 , meaning that with an increase in strategic sourcing of $1 \%$, it will increase the supply chain agility performance by $14.51 \%$. Based on the conclusions above, that MSMEs involved in sleman 
traditional markets are in line with the above theory, where MSME managers can achieve long-term goals by collaborating with employees and suppliers to develop in the business environment to compete with their competitors. In addition, using the strategy of purchasing and information sharing can influence the agility of MSMEs.

\subsection{Relationship of Variable Supply Chain Agility with Firm Performance}

Based on the results of the analysis in this study, there is a significant positive effect of Supply Chain Agility on firm performance in SMEs operating in the traditional market of Sleman Regency. Based on data processing (table 4) it is known that the CR value is 2.544 and the $P$ value is 0.011 . These results indicate that the $C R$ value is above 1.96 and the $P$ value is below 0.05 . The estimated value in relation to these two variables is 1.61 , meaning that with an increase in strategy orientation of $1 \%$, it will improve supply chain agility performance by $16.1 \%$.

The definition above is in line with this research where in order to improve the performance of MSMEs, managers must be agile and agile to face the challenges of competitors and make innovations in the field of technology so that they are not outdated. MSMEs can work together with each other aimed at advancing the economy of the surrounding community, where the agency helps to infrastructure, helps with funding and socialization. There are several types of socialization carried out by the service, including socialization related to serving consumers, socializing the use of technology and so on. Whereas MSMEs arein the vanguard of carrying out business. This supports the performance of MSMEs in the traditional sleman market, depending on how the managers of MSMEs use it.

\subsection{Relationship of Variable Strategic Sourcing to Firm Performance}

Based on the results of the analysis prove that this study has no significant effect on strategic sourcing on firm performance in MSMEs operating in the Sleman market traditional market. Based on data processing (table 4) it is known that the value of CR 0.39 and the $P$ value of 0.696 . These results indicate that the $C R$ value is below 1.96 and the $P$ value is above 0.05 . These results indicate that there is no significant effect of strategic sourcing on firm performance in MSMEs operating in Sleman Regency traditional market. The estimated value in the relationship of these two variables is 0.147, meaning that with an increase in strategic sourcing of $1 \%$, it will reduce firm performance by $14.7 \%$.

Thus, it can be concluded that MSME managers in the sleman traditional market have not been able to make a purchasing strategy, unite the internal parts of MSMEs, share information and work with suppliers. But the things done by the manager are not enough to increase the performance of MSMEs. In the traditional market, there are many changes and developments, but visitors still tend to go down. Various sources that explain the lack of competition with competitors who get purchasing strategies and work with suppliers better than MSMEs.

\section{Acknowledgment}

The preferred spelling of the word "acknowledgment" in America is without an "e" after the " $\mathrm{g}$ ". Avoidthestilted expression,"Oneofus(R.B.G.)thanks..."Instead,try“R.B.G.thanks”.Putapplicablesponsoracknowledgmentshere;DONOTplaceth emonthefirstpageofyourpaperorasafootnote.

\section{References}

i. Anwar, J. \&. (2017). Strategy-performance relationships: A comparative analysis of pure, hybrid. Journal of Advances in Management Research, Emerald Insight, 14(4), 446-465.

ii. Apte, A. R. (2011). An optimization approach to strategic sourcing:A case study of the united states air force. Journal of Purchasing and Supply Management, , 17(4), 222-230.

iii. Barua, S. K. (2013). Supply chain agility for firm's performance: a study of textile-apparel-retail supply chain network . Int. J. Agile Systems and Management, Vol. 6, No. 3, 2013 .

iv. Bastian, I. (2001). Akuntansi Sektor Publik di Indonesia.Edisi Pertama. Yogyakarta: BPFE.

v. Braunscheidel, M. N. (2009). The organizational antecedents of a firm's supply chain agility for risk mitigation and response. . Journal of Operations Management, 27(2), 119-140.

vi. Carr, A. a. (2002). The impact of purchasing and supplier involvement on strategic purchasing and its impact on firm's performance. International Journal of Operations \& Production Management, Vol. 22 No. 9, pp. 1032-53.

vii. Chai, M. K. (2017). The impact of supplier innovativeness, information sharing and strategic sourcing on improving supply chain agility: Global supply chain perspective. Intern. Journal of Production Economics, http:/ / dx.doi.org/10.1016/j.

viii. Charles, A. M. (2010). A model to define and assess the agility of supply chains: building on humanitarian experience. International Journal of Physical Distribution \& Logistics Management, 40(8/ 9), 722-741.

ix. Chiang, C.-Y. C.-H. (2011). An empirical investigation of the impact of strategic sourcing and flexibility on firm's supply chain agility. International Journal of Operations \& Production Management, 32(1), 49-78.

x. DeGroote, S. T. (2013). The impact of IT on supply chain agility and firm performance: An empirical investigation. . International Journal of Information Management, 33(6), 909-916.

xi. ekonomi.bisnis.com.(2019, $01 \quad$ 09).https:// ekonomi.bisnis.com. Retrieved fromekonomi.bisnis.com: https:/ / ekonomi.bisnis.com/ read/ 20190109/ 12/ 876943/ kontribusi-umkm-terhadap-pdb-2019-diproyeksitumbuh-5

xii. Goldman, S. N. (1994). Agile Competitors and Virtual Organizations: Strategies for Enriching the Customer. Van Nostrand Reinhold, New York, NY.

xiii. Injazz J. Chena, A. P. (2004). strategic purchasing, supply management, firm performance. journal of operations management, 22(2004) 505-523 doi:10.1016/j.jom.2004.06.002. 
xiv. Khan, S. d. (2006). "Benchmarking and competency mapping at TRIM India Ltd: a case study", in Jaiswal, M. and Garg, R.K. (Eds),. Bridging Global Digital Business Divide, Macmillan, New delhi.

xv. Kidd, P. (2000). Two definitions of agility. available at: www.cheshireHenbury.com (accessed March 19, 2007).

xvi. Kim, T. H. (2012). EXPLORING THE SUPPLY CHAIN AGILITY ATTRIBUTES IN FAST MOVING CONSUMER GOODS INDUSTRY: A CASE STUDY IN THE MIDDLE EAST. European, Mediterranean \& Middle Eastern Conference on Information Systems 2012.

xvii. Li, L. S. (2014). A study of network-building HR practices for TMT, strategic flexibility. Nankai Business Review, 5(1),95-114.

xviii. Murthy, S. G. (2008). Achieving supply chain agility through IT integration and flexibility. International Journal of Production Economics, 116 (2), 288-297.

xix. Nagel, R. N. (1991). 21st century manufacturing enterprise strategy: An industry-led view (1/2). Bethlehem, PA: Iacocca Institute, Lehigh University .

xx. Pauline Jeruto Keitany, D. J. (2017). EFFECT OF CROSS-FUNCTIONAL INFORMATION SHARING ON SUPPLY CHAIN AGILITY OF COSMETICS MANUFACTURING FIRMS IN THE COUNTY GOVERNMENT OF NAIROBI, KENYA . International Journal of Business and Management Review, Vol.5, No.8, pp.12-29, October 2017.

xxi. Paulraj, A. a. (2007). Environmental uncertainty and strategic supply management: a resource dependence perspective and performance implications. Journal of Supply Chain Management, , Vol. 43 No. 3, pp. 29-42.

xxii. Rajesh K. Pillania, A. K. (2008). Strategic sourcing for supply chain agility and firms' performance A study of Indian manufacturing sector. Management Decision, 46(10), 1508-1530.

xxiii. Sarrico, C. S. (2012). School performance management practices and school. International Journal of Productivity and Performance Management, 272-289.61(3).

xxiv. Schermerhorn, d. (2010). Organizational Behaviour. E Wiley.

xxv. Sinha, P. A. (2011). "What motivates manufacturing SMEs to outsource offshore in China?: comparing the perspectives of SME manufacturers and their suppliers. Strategic Outsourcing: An International Journal, Vol. 4 No. 1, pp. 67-88.

xxvi. Smeltzer, A. S. (1999). The Relationship Among Purchasing Benchmarking, Strategic Purchasing, Firm Performance, and Firm Size. The Journal of Supply Chain Management: A Global Review of Purchasing and Supply Copyright ( $)$ November 1999, by the National Association of Purchasing Management, Inc.

xxvii. Srimindarti, C. (2004). Balanced Scorecard sebagai Alternatif untuk Mengukur kinerja. Fokus Ekonomi, jilid 3 5264.

xxviii. Suresh, K. d. (2006). Strategic sourcing: an empirical investigation of the concept and its practices in US manufacturing firms. Journal of Supply Chain Management, Vol. 42 No. 2, pp. 4-16.

xxix. Titus Wachira Kihanya, M. K. (n.d.). The Role of Strategic Sourcing on Organization's Performance: A Case Study of Jomo Kenyatta University of Agriculture and Technology.

xxx. Tomljenović, L., \& Stilin , A. (2010). Research Of Ambidextrous Orientation In Croatian Smes. Entrepreneurship, 105-117.

xxxi. Van Hoek, R. (1998). "Measuring the unmeasurable measuring performance in the supply chain". Supply Chain Management: An International Journal, Vol. 3 No. 4, pp. 187-92. 